Didaché: Journal of Christian Education

Vol. 2, No. 1 (2021): 41-57

e-ISSN: 2722-8584

Published by: Sekolah Tinggi Teologi Simpson Ungaran

DOI: $10.46445 /$ djce.v2i1.365

\title{
Aktualisasi Misi dan Pemuridan Guru Pendidikan Agama Kristen Dalam Era Disrupsi
}

\author{
Tenny Tenny ${ }^{1} \&$ Yonatan Alex Arifianto ${ }^{2 *}$ \\ 1Sekolah Tinggi Teologi Duta Panisal, 2Sekolah Tinggi Teologi Sangkakala, Salatiga \\ Email: 1tenny@sttdp.ac.id, 2*arifianto.alex@sttsangkakala.ac.id
}

\begin{abstract}
Christian Religious Education teachers play a significant role in determining the spiritual increase of students. However, there are still many who do not realize and respond to the current state of disruption. They are less focused on students and prioritize cognitive only so that efforts to fulfill the Great Commission of the Lord Jesus are less significant results or developments in this era of disruption. To further discuss the actualization of the mission and discipleship of Christian Religious Education teachers in the era of disruption, the author uses the library research method in this discussion. The role of Christian religious education teachers in Mission and Discipleship must be the main goal through education that prioritizes and cares for the generation of the era of disruption. By equipping the understanding of God's Great Commission in mission education for Christian Religious Education teachers, they can be encouraged to improve teaching and learning methods. The purpose of this discussion is that the actualization of the mission and discipleship of Christian Religious Education teachers in an era of disruption can bring growth and development for the progress of God's church to be filled with true disciples of Christ.
\end{abstract}

Keywords: Role of teachers of Christian education, Disruption Era, Great Mandate

\begin{abstract}
Abstrak
Guru Pendidikan Agama Kristen memegang peranan yang sangat penting dalam menentukan meningkatnya kerohanian peserta didik, tetapi masih banyak yang belum menyadari dan meresponi keadaan era disrupsi saat ini.Mereka kurang berfokus kepada peserta didik dan cenderung mengutamakan kognitif saja, sehingga upaya pemenuhan Amanat Agung Tuhan Yesus kurang diperoleh hasil atau perkembangan yang signifikan dalam era disrupsi ini. Guna membahas lebih dalam mengenai aktualisasi misi dan pemuridan guru Pendidikan Agama Kristen dalam era disrupsi, pembahasan ini penulis menggunakan metode penelitian pustaka. Peranan Guru pendidikan agama Kristen dalam Misi dan Pemuridan harus menjadi tujuan utama melalui pendidikan yang mengutamakan pertumbuhan rohani dan peduli kepada generasi era disrupsi. Dengan membekali pemahaman Amanat Agung Tuhan dalam pendidikan misi bagi guru Pendidikan Agama Kristen, mereka dapat didorong pada peningkatan kualitas pengajaran maupun secara metode pembelajaran. Tujuan pembahasan ini, diharapkan aktualisasi misi dan pemuridan guru Pendidikan Agama Kristen dalam era disrupsi
\end{abstract}


dapat membawa pertumbuhan dan perkembangan bagi kemajuan gereja Tuhan dipenuhi dengan murid-murid Kristus yang sejati.

Kata kunci: Peranan guru PAK, Era Disrupsi, Amanat Agung

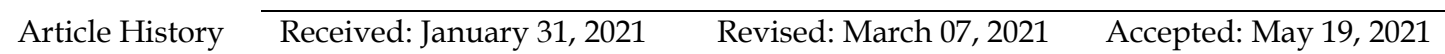

This is an open access article under the CC BY-SA license

\section{Pendahuluan}

Banyak orang yang mengklaim dirinya memiliki panggilan sebagai guru Pendidikan Agama Kristen, namun banyak pendidik belum memahami dengan benar mengenai perannya dalam pelaksanaan misi Allah dan pemuridan. Menurut Manullang (2019) peranan guru Pendidikan Agama Kristen dalam pemuridan sangat penting agar peserta didik mengenal Kristus sebagai Tuhan dan Juruselamat. Pemuridan tersebut dilakukan bukan hanya sebuah tugas dari lembaga pendidikan, tetapi hasrat dan upaya yang lahir dari dalam diri seorang pendidik dan hal tersebut akan mempengaruhi kehidupan iman Kristen peserta didiknya, dalam era disrupsi sekarang ini (Ina, 2018). Walaupun tugas dan peran seorang guru Pendidikan Agama Kristen sebagai fasilitator pemuridan namun hal itu bukanlah sebuah pekerjaan yang ringan dan mudah untuk dilakukan dalam era disrupsi ini (Onglo, 2020).

Upaya misi dan pemuridan sejatinya mendorong pertumbuhan rohani anak didik yang akan berkorelasi terhadap pertumbuhan karakter, moral dan perilaku mereka menjadi generasi yang takut akan Tuhan dalam era disrupsi ini (Ermindyawati, 2019). Era disrupsi merupakan situasi dan kondisi yang sebenarnya terjadi akibat dari perubahan dari proses keadaan industri sebagai hasil perkembangan teknologi informasi dan berpotensi menggantikan sistem lama dengan teknologi digital (Suwardana, 2018). Kasali (2018b), mengungkapkan bahwa era disrupsi merupakan sebuah era peralihan, dimana informasi yang menyebar di media sosial dengan semakin cepat dan efisien, sehingga menimbulkan efek pembaruan informasi secara cepat, masif dan berpengaruh tanpa disadari. Oleh karena itu masa peralihan telah mengubah paradigma manusia berbeda dari era sebelumnya, dan perkembangan ini membawa manusia di era yang penuh optimis, cerdas, dan serba praktis dalam melakukan transaksi. Begitu juga yang dinyatakan oleh Kasali bahwa era disrupsi adalah adanya perubahan yang terjadi dengan nyata sebagai akibat hadirnya masa depan ke masa kini (Kasali, 2018a). 
Jika guru Pendidikan Agama Kristen tidak melaksanakan misi dan pemuridan, maka Amanat Agung tidak berjalan sebagaimana mestinya dan mengakibatkan tidak ada pertumbuhan jumlah jiwa-jiwa dan pertumbuhan spiritual dari peserta didik. Misi yang merupakan perintah Tuhan Yesus Kristus, harus diaktualisasikan sebagai pertanggungjawaban kepada Tuhan. Oleh karena itu seorang Pendidik Agama Kristen sangat dituntut memiliki penguasaan firman Tuhan, dan memiliki panggilan yang kuat sebagai pendidik untuk menghasilkan jiwa-jiwa bagi Tuhan. Tetapi kendala yang nyata terjadi dalam dunia pendidikan saat ini adanya tenaga pendidik yang belum menguasai firman Tuhan dengan baik (Rampa, 2020), juga adanya orang tua siswa belum memperkenalkan Kristus kepada anak-anaknya, karena kurang memahami firman Tuhan (Ngau, 2019). Oleh karena itu, inilah yang membuat guru dan murid tidak maksimal menjadi agen dari Amanat Agung dalam mengaktualisasikannya. Namun yang seharusnya adalah guru Pendidikan Agama Kristen dituntut memiliki panggilan yang jelas dan penyerahan yang total dalam mengajar seperti halnya melayani Tuhan, sehingga akan bekerja keras untuk memuliakan-Nya. Setiap guru Kristen hendaknya menyadari bahwa dirinya adalah pemegang Amanat Agung dimanapun mereka ditempatkan (Prijanto, 2017).

Berkaitan dengan topik aktualisasi misi dan pemuridan guru Pendidikan Agama Kristen dalam era disrupsi juga pernah diteliti oleh Purnomo dan Sanjaya (2020) dengan tantangan dan strategi gereja menjalankan misi Allah dalam menghadapi penerapan industri 4.0 di Indonesia. Penelitian Purnomo dan Sanjaya (2020) menyimpulkan bahwa digitalisasi sebagai ekosistem baru memberikan peringatan apakah gereja akan bertransformasi atau ditransformasikan oleh digitalisasi sehingga cepat atau lambat akan meninggalkan era reformasi dan memasuki dunia yang baru di dalam sejarah misi dan perkembangan gereja. Munthe (2019) melakukan penelitian serupa dengan kesimpulan bahwa kebutuhan gereja yang semakin erat kaitannya dengan pola hidup serba digital ini membutuhkan orang-orang yang dapat melayani Tuhan dengan memiliki kemampuan mengaktualisasikan dirinya melalui berkembangnya zaman ini. Sehingga pemberdayaan jemaat harus dimulai dari pemimpin yang telah lebih dahulu berdaya dalam karunia yang dapat diterapkan untuk kegiatan misi di era digital ini. Berdasarkan kedua penelitian tersebut masih ada hal-hal yang belum diteliti yaitu tentang aktualisasi misi dan pemuridan guru pendidikan agama Kristen dalam era disrupsi oleh sebab itu artikel ini akan meneliti dan membahas tentang topik tersebut. 
Persoalan utama adanya para tenaga pendidik masih sangat kurang dalam aktualisasi misi menjadi titik tolak guru untuk terus memberikan pemahaman bahwa Kekristenan harus diwujudkan lewat kesaksian hidup seperti yang diperintahkan Tuhan menjadi garam dan terang dunia. Dari hal itu aktualisasi dapat dinyatakan dalam setiap kehidupan guru dan murid untuk memberitakan Injil melalui media apa saja yang dapat menjangkau orang lain agar menerima Yesus sebagai Tuhan. Sedangkan konsep pemuridan harus diprioritaskan dalam membangun komunitas guru dan siswa yang siap menjadi pribadi yang tunduk dan taat akan kebenaran firman Tuhan.

Di dalam era disrupsi para peserta didik yang lebih banyak menerima makanan bagi jiwa mereka berasal dari konten-konten dunia yang bersifat negatif bagi generasi ini. Hal tersebut dapat menyebabkan peserta didik memilikikrisis identitas dan krisis iman, karena konten duniawi yang negatif tersebut menyesatkan mereka, yang dalam era disrupsi saat ini tidak dapat dihindari. Segala sesuatunya dapat menjadi konsumsi peserta didik bahkan hal-hal yang melampaui batas etika dan moral manusia, dengan demikian peranan penting dari guru Pendidikan Agama Kristen dalam aktualisasi misi dan pemuridan agar peserta didik tidak terseret arus duniawi yang negatif (Telaumbanua, 2018). Maka para tenaga pendidik harus memaksimalkan fungsi dan perannya dalam aktualisasi misi dan pemuridan bagi kepentingan Kristus. Peran guru Pendidikan Agama Kristen harus berjalan dengan baik, dan mencapai pemahaman yang benar mengenai Amanat Agung guna memperlengkapi mereka dalam pelaksanaan misi dan pemuridan demi kerohanian peserta didik dalam era disrupsi sekarang ini.

\section{Metode}

Jenis penelitian dalam paper ini adalah penelitian pustaka dengan pendekatan kualitatif deskriptif (Umrati \& Wijaya, 2020). Penulis melakukan kajian terhadap sumber-sumber pustaka dan menguraikannya dalam sebuah kerangka uraian dengan mendeskripsikan aktualisasi misi dan pemuridan guru Pendidikan Agama Kristen dalam era disrupsi secara praktis. Selain menggunakan Alkitab sebagai referensi primer, juga dipergunakan buku-buku dan sumber-sumber primer lain yang relevan dengan topik sesuai prinsip literatur review yang dimaksud oleh Denney dan Tewksbury (2013). Paper ini dijabarkan secara deskriptif guna dapat ditemukan sebuah bentuk aktualisasi misi dan pemuridan guru Pendidikan Agama Kristen dalam era disrupsi. 


\section{Hasil dan Pembahasan}

Bagian ini merupakan pembahasan secara tematik mengenai aktualisasi misi dan pemuridan guru Pendidikan Agama Kristen dalam era disrupsi. Hal ini dimaksudkan agar dapat menemukan suatu gambaran yang menolong para pembaca dalam memahami aktualisasi misi dan pemuridan di era disrupsi secara jelas, dan dapat memberikan inspirasi dan menyadarkan setiap pembaca agar memenuhi Amanat Agung Tuhan Yesus dalam kehidupannya sehari-hari sebagai pribadi yang dipercaya dalam mengajar sebagai guru Pendidikan Agama Kristen.

\section{Peranan Guru Pendidikan Agama Kristen dalam Misi Dan Pemuridan}

Pendidikan Agama Kristen yang dilaksanakan di sekolah-sekolah masih belum dilakukan secara menyeluruh, kebanyakan hanya mengajarkan doktrin Kristen secara teori saja dan pada praktiknya masih bersifat satu arah, kebanyakan guru Pendidikan Agama Kristen hanya sampai pada menunaikan tugas dan kewajiban secara akademis saja (Andriani, 2013). Namun jika kembali kepada Amanat Agung Tuhan Yesus Kristus, para peserta didik harus menjadi murid Kristus dan menjadi agen misi gunamenjangkau jiwa-jiwa bagi kerajaan Allah. Para peserta didik akan mengalami pertumbuhan iman dan kerohaniannya seiring dengan pemahaman Alkitab yang baik melalui pelaksanaan misi dan pemuridan secara intens kepada mereka (Situmorang, 2017). Oleh karena itu kegiatan pemuridan merupakan hak bagi setiap peserta didik untuk mendapatkan pengenalan akan Tuhan dan pertumbuhan iman oleh kebenaran firman Tuhan (Rampa, 2020). Sudah seharusnya pengajaran Pendidikan Agama Kristen menjadi sebuah metode pembelajaran, misi dan pemuridan bagi para peserta didik (Purba, 2014) dan juga merupakan cara yang efektif dalam menggerakkan dan mengembangkan jiwa-jiwa yang dilakukan sesuai dengan Amanat Agung dalam Matius 28:19-20 (Subekti \& Pujiwati, 2019). Terlebih dengan narasi memberikan perhatian kepada kegiatan Allah, perhatian kepada Injil sebagai cerita komunitas iman Kristen dan visi kerajaan Allah untuk keselamatan manusia (Mary \& Darmawan, 2018).

Seorang guru harus menyadari bahwa tujuan utama dari pendidikan agama Kristen adalah melaksanakan Amanat Agung (Andriani, 2013). Guru Pendidikan Agama Kristen juga harus memiliki ekspektasi dan kepedulian yang tinggi terhadap peserta didik dalam mengembangkan pertumbuhan rohani mereka dalam era disrupsi ini (Handoko, 2021). Kehidupan rohani dari seorang 
guru Pendidikan Agama Kristen harus menjadi perhatian besar dalam lembaga pendidikan karena hal tersebut berkaitan dengan pengajaran yang diberikan kepada peserta didiknya. Seorang guru Pendidikan Agama Kristen apabila memiliki kerohanian yang baik, maka hal tersebut akan menjadi teladan serta pola bagi peserta didik. Dan juga guru memaksimalkan pengetahuan akan Firman sesuai dengan doktrin Kristen yang diajarkannya (Lase \& Hulu, 2020). Guru Pendidikan Agama Kristen yang merupakan seseorang yang memiliki tugas dan tanggung jawab, serta menjadi ujung tombak di dunia akademis dalam memenuhi misi Tuhan Yesus yang terwujud dalam pribadi seorang guru Pendidikan Agama Kristen. Sehingga melalui kesaksian hidupnya sehari-hari sebagai saksi Kristus dapat menjadi dampak positif (Kia, 2017).

Kesaksian hidup tercermin melalui pola hidupnya, komitmen, maupun misinya, dan kecintaannya kepada Kristus menjadi landasan bagi kecintaannya terhadap peserta didik dan membangun mereka menjadi tubuh Kristus (Handoko, 2021). Dalam era disrupsi tentu saja akan ada banyak tantangan dalam aktualisasi misi dan pemuridan, baik itu datang dari dalam diri sendiri maupundari faktor eksternal (Yanti, 2020). Hambatan pribadi dalam memenuhi Amanat Agung Tuhan Yesus, dari diri sendiri yang tidak memiliki keberanian dan tidak memiliki kemampuan untuk aktualisasi misi serta pemuridan (Yen, 2019). Dalam pelaksanaan misi dan pemuridan di era disrupsi atau disebut era 4.0 telah menjadi sebuah tantangan yang berbeda dari yang ada pada umumnya (Munthe, 2019). Namun tantangan dari luar juga ada seperti tantangan penginjilan masa kini adalah menghadapi fanatisme agama. Fanatisme agama yang terjadi saat ini memerlihatkan semangat yang tidak rasional, terlebih bisa menggunakan kekuatan untuk memaksa orang untuk percaya dan berusaha menumpas yang tidak percaya (Stevanus, 2020). Peranan guru pendidikan agama Kristen diharapkan dapat menjadi sebagai seorang pengajar, pelatih, penginjil, fasilitator, motivator, pemimpin, evaluator, komunikator, bahkan teolog (Andriani, 2013). Peran guru juga dapat mensupervisi pertumbuhan kerohanian dan sebagai kesaksian iman bagi peserta didik, bukan sekedar menyampaikan pengetahuan saja, tetapi sebagai konselor, mendampingi, membimbing dan mengarahkan peserta didik yang sedang mengalami berbagai persoalan (Silaban, 2018). Menjadi guru Pendidikan Agama Kristen yang menabur benih firman Tuhan, memperkenalkan Yesus Kristus, memperkenalkan Alkitab dan gereja kepada peserta didik, adalah tugas yang harus dilaksanakan dengan penuh tanggung jawab. Guru Pendidikan Agama Kristen 
harus selalu siap untuk mengaktulisasi dan menyambut dengan ramah serta menjawab pertanyaan-pertanyaan para peserta didik. Tentunya hal itu memberikan energi ekstra bagi guru Pendidikan Agama Kristen yang memikirkan kepentingan peserta didik demi Kristus (Handoko, 2021).

Dari pembahasan di atas, ada nilai yang sangat penting bahwa betapa seriusnya peranan guru Pendidikan Agama Kristen bagi para peserta didik secara khusus dalam era 4.0, bukan sekedar menjadi fasilitator secara akademis, tetapi harus sebagai guru Pendidikan Agama Kristen yang berhasil memenuhi Amanat Agung Tuhan Yesus dengan menyampaikan kebenaran yang hakiki sebagai dasar kerohanian dalam mengiring Yesus. Terlebih dituntut untuk menunjukan pola prilaku guru yang sejalan dengan perilaku Yesus Kristus sang Guru Agung (Mary \& Darmawan, 2018).

\section{Generasi Era Disrupsi}

Era disrupsi menunjuk pada suatu keadaan mengalami peralihan ke dalam bidang teknologi dan informasi yang telah memanifestasikan sebuah perubahan yang sangat mendasar terhadap sistem kehidupan sosial masyarakat, khususnya kehidupan anak-anak dan generasi muda di sekolah, gereja, dimana budaya instan, berbagai kemudahan dan kegiatan kehidupan dunia nyata beralih ke dunia maya (Ngalimun, 2020). Setiap waktu dapat ditemukan informasi online yang bersifat destruktif, contohnya penyebaran berita hoax, bullying, penipuan, ujaran kebencian/provokasi, prostitusionline, pornografi, dan lain sebagainya (Ngalimun, 2020). Dapat dikatakan bahwa perubahan atau era disrupsi jika tidak dibarengi dengan aktualisasi misi dan pemuridan yang sungguh-sungguh dilaksanakan oleh guru Pendidikan Agama Kristen, maka hal ini akan menjadi ancaman yang serius dan problematika iman dan moralitas anak-anak dan generasi muda.

Guru Pendidikan Agama Kristen harus terbuka dan menerima keadaan dunia sudah berbeda sehingga jangan lamban menanggapi perubahan yang ada. Karakter para peserta didik berubah seiring dengan adanya generasi digital. Generasi jaman ini sebagai pengguna digital yang sangat aktif seperti menggunakan Instagram, Tiktok dan sebagainya. Berkaitan dengan aktualisasi misi dan pemuridan, guru Pendidikan Agama Kristen perlu berada di platform yang sama dengan peserta didik dimana guru Pendidikan Agama Kristen mengikuti yang sedang tren di kalangan anak didik dengan konten tentang pemberitaan Yesus yang kreatif, dan juga digunakan untuk tujuan memuliakan Tuhan. Oleh 
sebab itu di era disrupsi, guru harus memaksimalkan teknologi dan kecanggihan komunikasi menjadi sarana dalam penginjilan. Memang jelas terdapat sebuah perubahan sudut pandang dalam dunia pendidikan yaitu saat ini berpusat kepada peserta didik (Grafura \& Wijayanti, 2019). Oleh karena itu tugas guru menjadi berubah. Contohnya dulu banyak aktifitas guru menerangkan, tetapi sekarang memunculkan sifat kritis peserta didik, dulu guru banyak memberikan PR untuk dikerjakan di rumah, saat ini memunculkan ide peserta didik untuk mencari inovasi, dan dulu banyak memberikan punishment, sekarang memberi banyak motivasi kepada peserta didik (Grafura \& Wijayanti, 2019).

Guru Pendidikan Agama Kristen juga harus mempelajari dan mengenali kelemahan generasi era disrupsi. Mereka terbiasa hidup serba instan dan hal ini membuat peserta didik menjadi anak-anak yang mudah sekali patah semangat dan pesimis. Ada kasus-kasus yang diberitakan di media mengenai remaja bunuh diri, hanya karena mengalami kesulitan belajar saja (Pratiwi, 2020). Kemudian dalam hal mencari berbagai informasi saat ini sangat luar biasa bebas dan anak-anak tidak mampu memilih konten yang layak untuk mereka lihat di dunia digital. Kasali (2017) memberi julukan generasi stoberi kepada anak-anak muda jaman ini, generasi yang tampak segar tetapi mudah lecet.Grafura dan Wijayanti (2019) memberi gambaran fenomena saat terjadi pohon tumbang di tengah jalan, mereka bukannya ikut membantu memindahkan pohon tersebut dari jalan, tetapi malah foto-foto dan memposting di media sosial mereka sambil menyalahkan dinas terkait mengenai hal tersebut. Oleh karena itu guru-guru Pendidikan Agama Kristen perlu berbenah diri dalam menghadapi era disrupsi ini. Metode pembelajaran yang terlalu kognitif masih belum ditinggalkan, guru yang banyak bicara dan murid duduk dengan tenang, padahal tidak semua peserta didik mampu berprestasi karena mereka diberikan metode pembelajaran yang sudah tidak cocok lagi dengan era disrupsi (Grafura \& Wijayanti, 2019).

\section{Amanat Agung Tuhan Yesus}

Perintah utama Tuhan Yesus: menjadikan segala bangsa murid-Nya (Mat. 28:19-20a) dan ini merupakan sebuah aktivitas. Alkitab versi Indonesia terjemahan baru mencatat ada empat kata perintah; pergilah, jadikanlah, baptislah dan ajarlah. Namun di dalam kajian sintektikalnya diketemukan bahwa tidak semua kata itu menggunakan bentuk imperatif. Dari keempat kata itu, hanya satu yang menggunakan bentuk imperatif yaitu "jadikanlah semua bangsa murid-Ku" (Dwiraharjo, 2019). 
Kata pergi disini berasal dari kata Yunani $\pi о \rho \varepsilon v \theta \varepsilon v \tau \varepsilon S$ (poreuthentes) menggunakan tata bahasa partisipel, aorist, pasif. Kata ini menerangkan kata kerja adjektif, yang maknanya bahwamemberitakankabar baiksebagai gaya hidup orang percaya (Bibleworks, n.d.). Jadi dimanapun orang percaya berada selalu memberitakan kabar baik karena itulah gaya hidup yang diperintahkan Tuhan (Dwiraharjo, 2019). Selaras dengan hal tersebut, Arifianto, Oktavia, \& Dwikoryanto (2020) mengungkapkan bahwa memberitakan Injil harus dilakukan dengan rela hati kepada semua orang supaya hal ini tetap menjadi gaya hidup dalam kerendahan hati dalam menginjil.

Dalam Frase kata jadikanlah semua bangsa murid-Ku, dari kata mathetesate menggunakan tata bahasa imperatif, aorist, aktif (Bibleworks, n.d.). Bentuk imperatif disini untuk menegaskan suatu perintah atau desakan yang dianggap sangat penting. Sebuah perintah bahwa orang percaya harus menjadikan segala bangsa murid Tuhan Yesus, sebuah tugas yang dilakukan secara aktif (Dwiraharjo, 2019). Pernyataan kepada segala bangsa disini merujuk bahwa anugerah Tuhan Yesus melalui perintah Amanat Agung supaya mereka pergi kepada bangsa non-Yahudi. Pengharapan bangsa Yahudi memiliki akan Mesias yang akan memerintah bangsanya sendiri, namunTuhan Yesus ingin mereka membawa segala bangsa datang menjadi murid-Nya (Dwiraharjo, 2019), dan penginjilan harus didasari dari motivasi yang benar dalam membawa kabar keselamatan bagi jiwa-jiwa yang terhilang dan belum mengenal Yesus sebagai juruselamat (Arifianto \& Purnama, 2020).

Perintah baptislah dalam nama Bapa, Anak dan Roh Kudus. Kata baptislah baptisontes bentuk partisipel, present, aktif. Present partisipel yang biasanya digunakan untuk mencatat progresivitas suatu tindakan, atau rangsangan dengan suatu tindakan, juga bisa digunakan untuk mengidentifikasikan suatu tindakan (MySabda Team, 2021). Pembaptisan dapat dinilai sebagai sebuah hasil yang berasal dari proses memuridkan. Dan pembaptisan harus dilakukan dalam Nama Bapa, Anak dan Roh Kudus (Dwiraharjo, 2019), orang percaya diperintahkan untuk menjadikan semua bangsa murid Kristus serta membawa mereka terus menerus mengalami pengenalan akan Yesus Kristus sebagai JuruselamatNya dan membaptis mereka yang telah percaya atas nama Bapa, Anak dan Roh Kudus.

Kemudian ajarlah mereka melakukan segala sesuatu. Kata ajarlah didaskontes menggunakan bentuk grammar partisipel, present, aktif. Grammar yang digunakan ini sama dengan kata baptisan, sehingga dengan demikian 
secara gramatikal memiliki tekanan yang sama, yaitu menekankan suatu progresivitas dari tindakan pengajaran. Ajarlah mereka melakukan segala sesuatu, semua kewajiban kepada Allah dan kepada manusia, semua tugas yang ada di dunia (MySabda Team, 2021) dalam semua bidang, bukan hanya baptisan tetapi juga perjamuan Tuhan, juga termasuk tugas-tugas moral, pelayanan firman Tuhan dan menjadi pelaku-pelaku firman Tuhan (Dwiraharjo, 2019).

Melalui landasan Amanat Agung yang telah dibahas, jelas bahwa aktualisasi misi dan pemuridan merupakan pemenuhan Amanat Agung Tuhan Yesus Kristus (Yen, 2019). Tujuan dari Injil adalah jadikanlah segala bangsa menjadi murid Kristus, bangsa disini lebih tepatnya segala ras (Putra, 2018), lalu membaptiskan mereka (Fitriyana \& Murtiningsih, 2019), kemudian mengajarkan mereka melakukan segala sesuatu yang Tuhan Yesus Kristus perintahkan (Pawson, 2015). Hal ini dirancang untuk mengajarkan mereka bagaimana hidup sebagai murid Kristus dan proses memuridkan perlu waktu bertahun-tahun atau ini adalah sebuah proyek jangka panjang, mengajarkan kepada mereka bagaimana gaya hidup kerajaan Allah di bumi, injil Matius menuliskan tujuan tersebut menyatakan sebuah kerajaan Allah itu nyata dan dapat disentuh, seperti dalam ajaran kotbah di bukit mengenai gaya hidup kerajaan Allah, semua yang Tuhan Yesus ajarkan tentang menjadi manusia baru yang masuk berpindah ke dalam kerajaan Allah (Pawson, 2015).

Dalam misi kerajaan Allah dimana guru harus mengajarkan mereka untuk pergi keluar dan membawa jiwa-jiwa yang lain ke dalam kerajaan Allah dan seperti yang tertulis dalam Injil Matius pasal 9-10. Inilah caranya menginjil, pergi keluar, membangkitkan orang mati, mengusir setan dan menyembuhkan segala macam sakit penyakit (MySabda Team, 2021), lalu membimbing jiwa-jiwa untuk memenuhi Amanat Agung Tuhan Yesus, mengajarkan mereka untuk menghidupinya, bagaimana menyebarkannya, bagaimana bertumbuh, bagaimana hidup dalam komunitas keluarga Allah dan bagaimana menunggu jaman baru untuk menyambut kedatangan Kristus kembali dengan melakukan kebenaran yaitu melakukan kehendak Bapa di Surga (Pawson, 2015).

Dalam Injil Matius 28:18-20 janganlah hanya dipahami kata pergilah secara sempit hanya sebagai memberitakan Injil saja, tetapi terdapat juga kata "bertobatlah, sebab Kerajaan Allah sudah dekat" kata ini dipahami sebagai bentuk pemuridan (MySabda Team, 2021). Dalam Amanat Agung menjelaskan bahwa tanggung jawab gereja tidak hanya berupa kegiatan penginjilan saja, tetapi juga melaksanakan pemuridan yang dibuka bagi semua suku bangsa 
(Putra, 2018). Inti dari Amanat Agung Tuhan Yesus adalah landasan bagi orang percaya dalam memenuhi perintah Tuhan Yesus dalam aktualisasi misi dan pemuridan, tanggung jawab tersebut harus dilakukan secara sistematis dan praktis, agar semua yang diajarkan dengan mudahdipahami oleh semua peserta didik (Darmawan, 2019). Dalam Injil Matius memberikan gambaran dari keteladanan Tuhan Yesus kepada murid-murid-Nya, baik kehidupan seharihari, kehidupan spiritual. Pelayanan Yesus kepada banyak orang tidak memandang ras atau suku bangsa. Pengajaran Yesus yang penuh dengan kuasa, serta Yesus Kristus bertanggung jawab kepada Bapa untuk memindahkan setiap orang percaya dari kegelapan kepada kerajaan Allah dan otoritas kuasa yang sama telah dicurahkan bagi orang-orang percaya dalam melaksanakan Amanat Agung (Katarina \& Siswanto, 2018).

Dengan demikian pemahaman mengenai Amanat Agung, aktualisasi misi dan pemuridan yang harus dilakukan oleh guru Pendidikan Agama Kristen dalam era disrupsi, dimana jaman dan kebutuhan telah berubah total,sangat berbeda dengan zaman gereja mula-mula yang memang kemajuan teknologi belum ada. Dalam era 4.0 semua aspek dalam kehidupan manusia telah mengikuti dan menggunakan teknologi, maka tantangan dalam aktualisasi misi dan pemuridan yang dihadapi oleh tenaga pendidik tentu berbeda. Guru Pendidikan Agama Kristen harus menyesuaikan dengan kebutuhan era digital karena banyak kegiatan diadakan secara daring, baik itu sekolah maupun gereja-gereja. Mereka harus melakukan perubahan strategi dan pendekatan agar aktualisasi misi Amanat Agung dapat berjalan dengan baik (Hartono, 2018). Jadi Amanat Agung seharusnya akan lebih mudah dipahami oleh peserta didik ketika pengajaran disampaikan dalam konteks dan konsep era digital. Di era digital penjangkauan dapat dilakukan kepada seluruh populasi yang terhubung dengan Internet dalam waktu dan ruang yang berbeda, dengan demikian diharapkan esensi Amanat Agung dapat diserap oleh peserta didik. Dalam pelaksanaan misi, perlu diperhatikan dan dilakukan oleh gereja adalah menyediakan materi untuk isi (content) untuk disampaikan kepada peserta didik dalam media sosialnya (Arifianto, Saptorini, \& Stevanus, 2020).

Amanat Agung sebagai sebuah mandat, fondasi dan panduan dalam melaksanakan misi dan pemuridan. Melalui Amanat Agung ini, para tenaga pendidik di bidang Pendidikan Agama Kristen telah diberikan sebuah pedoman, pola dan sistem dalam aktualisasi misi dan pemuridan. Jadi Amanat Agung dijadikan sebagai landasan bagi pengajaran Pendidikan Agama Kristen 
(Tanduklangi, 2020) dan juga dijadikan prinsip perintah dari Tuhan Yesus (Oni, 2020) oleh guru Pendidikan Agama Kristen untuk memuridkan semua peserta didik tanpa membedakan ras, kemudian mereka dapat bertumbuh secara rohani serta menjadi agen misi bagi kerajaan Allah. Aktualisasi misi dan pemuridan ini juga dapat dipenuhi sesuai dengan kebutuhan dan konsep era digital, konten pengajaran dapat menggunakan media online bagi semua peserta didik.

\section{Pendidikan Misi Bagi Guru Pendidikan Agama Kristen}

Informasi Lembaga Pengkajian Bilangan Research Center tahun 2018, mengekspos mengenai pertumbuhan gereja ternyata didapatkan pertumbuhan gereja di Indonesia tidak mengalami jumlah yang signifikan (Widjaja, Ginting, \& Hutagalung, 2019). Muncul pertanyaan bagi masalah ini, apakah gereja kurang missioner? Secara khusus yang ingin dibahas disini, apakah guru Pendidikan Agama Kristen di sekolah dan gereja kurang aktualisasi misi dan pemuridan? Apakah guru Pendidikan Agama Kristen kurang mendapat pendidikan dan pelatihan misi?. Adanya peningkatan jumlah anggota jemaat di tiap gereja di Indonesia seringkali berasal dari perpindahan jemaat gereja lain atau simpatisan dari satu gereja ke gereja lainnya sebanyak 42,3\% dan jumlah anggota jemaat yang murni dari hasil aktualisasi misi dan pemuridan hanya berjumlah2,1 persen, hal ini menjadi alat ukur bahwa pertumbuhan gereja sangat kecil jumlahnya (Widjaja et al., 2019). Fakta bahwa anak-anak usia 15 tahun ke bawah jumlahnya kurang lebih dua milyar anakdengan kata lain sebanyak 26\% dari jumlah total penduduk dunia. Menurut catatan sejarah, anak-anak yang berusia 15 tahun ke bawah merupakan jumlah yang paling banyak mengambil keputusan untuk menerima Tuhan Yesus sebagai Juruselamat dan beriman kepadaNya (Tenibemas, 2019). Karena rentang usia 4 sampai 14 tahun, mereka yang paling membuka diri untuk beriman kepada Tuhan Yesus, secara prosentase sebanyak 85\% (Tenibemas, 2019). Selanjutnya mereka yang rentang usianya antara 15 sampai 30 tahun sebanyak 10\%. Sedangkan yang berusia di atas 30 tahun hanya 4 persen (Tenibemas, 2019). Dan yang terakhir pada anak yang usianya 4 tahun ke bawah berjumlah hanya 1\% dikarenakan masih kecil belum dapat memahami secara usia, maka bagi yang berusia 4 sampai dengan 14 tahun membutuhkan lebih banyak perhatian dalam pelayanan dan aktualisasi misi oleh guru Pendidikan Agama Kristen (Tenibemas, 2019).

Pendidikan dasar misi dapat menjadi gambaran bagi guru Pendidikan Agama Kristen, hal itu terdapat dalam kitab Perjanjian Lama dan Perjanjian Baru 
(Pawson, 2017), dimana Tuhan Yesus yang memiliki hati misi dan jiwa untuk memuridkan. Model pendidikan misi yang dilakukan oleh Tuhan Yesus dan Rasul-rasul ini, Tuhan Yesus memulai dari keduabelas orang murid kemudian mengutus ketujuhpuluh murid; yang dilakukan Tuhan Yesus dalam aktualisasi misi dan pemuridan adalah mengajar, melatih, memberi (Widjaja et al., 2019). Dalam Perjanjian Lama contoh tokoh Alkitab yaitu Yunus yang diperintahkan Allah untuk missioner ke kota Niniwe, perintah missioner tersebut terus dan masih berlaku sampai saat ini Allah dalam misi keselamatan kepada semua umat manusia di muka bumi (Widjaja et al., 2019).

Sejatinya Allah memiliki hak preogratif terhadap pelayanan-Nya, Ia dapat saja memakai semua orang percaya, hamba-hamba Tuhan, para misionaris (Widjaja et al., 2019), termasuk guru Pendidikan Agama Kristen. Mengingat Allah sendiri yang berinisiatif untuk mencari manusia berdosa dan hati Allah tidak pernah berubah. Mandat misi belum berhenti sampai kedatangan Kristus kembali, tugas penting ini harus dikerjakan dengan serius dan penuh tanggungjawab oleh guru Pendidikan Agama Kristen dalam mengaktualisasi misi dan pemuridan bagi peserta didik dimana pun mereka berada, karena orientasi guru Pendidikan Agama Kristen harus kepada jiwa-jiwa (Pawson, 2017).

Pendidikan misi bagi guru Pendidikan Agama Kristen dapat diperoleh dari sekolah-sekolah teologi dan lembaga-lembaga pelatihan misi. Tentunya penyiapan guru Pendidikan Agama Kristen bagi aktualisasi misi dan pemuridan dalam era disrupsi ini menjadi perhatian besar bagi sekolah maupun lembaga tersebut di atas untuk membekali dan memperlengkapi para guru dan semua yang diperlukan mereka dalam rangka pemenuhan Amanat Agung Tuhan Yesus (Tenibemas, 2019).

\section{Kesimpulan}

Peranan guru Pendidikan Agama Kristen sangat serius dan begitu pentingnya sebagai alat Tuhan dalam memberitakan pengajaran kebenaran firman Tuhan dimanapun waktu dan tempatnya, termasuk dalam dunia digital atau era disrupsi dengan metode maupun kreativitas yang dapat memberikan pengertian kepada semua orang. Guru juga dapat berperan menjadikan peserta didik sungguh-sungguh menjadi murid Kristus sejati. Tetapi tantangan dan kendala guru Pendidikan Agama Kristen dalam era disrupsi juga tidak mudah, maka dengan kekuatan dan kuasa dari Tuhan akan menguatkan guru Pendidikan Agama Kristen dalam menyikapi dan meresponi perubahan keadaan 
yang sangat cepat, dimana para guru harus cepat dalam mempelajari dan mengenali betul kelemahan generasi era disrupsi saat ini, dengan mengubah metode pembelajaran yang lebih efektif dalam aktualisasi misi dan pemuridan yang harus dipenuhi bagi generasi saat ini.

Peranan Guru Pendidikan Agama Kristen dalam Misi dan Pemuridan harus menjadi tujuan utama sebab melalui pendidikan yang mengutamakan pada pertumbuhan kerohanian juga peduli kepada generasi di era disrupsi. Dengan membekali diri lewat pemahaman Amanat Agung Tuhan dalam pendidikan misi bagi guru Pendidikan Agama Kristen. Sehingga melalui pemberian dukungan dan pelatihan misi yang memadai bagi para guru Pendidikan Agama Kristen, mereka dapat diperlengkapi secara kualitas pengajaran maupun metode pembelajaran. Jadi di dalam sebuah proyek pekerjaan Tuhan yang sangat besar ini, tidak mungkin jika satu pihak bekerja sendirian tanpa saling mendukung satu sama lain untuk mencapai tujuan Allah, dan tidak mencari kepentingan sendiri, namun demi kepentingan Kristus semata.

\section{Daftar Rujukan}

Andriani, S. (2013). Refleksi Guru Pendidikan Agama Kristen sebagai Misionaris di dalam Pendidikan. Jurnal Antusias: Jurnal Teologi Dan Pelayanan, 2(4), 116.

Arifianto, Y. A., Oktavia, K., \& Dwikoryanto, M. I. T. (2020). Studi Teologis Prinsip Penginjilan Paulus dalam 1 Korintus 9:16. LOGIA: Jurnal Teologi Pentakosta, 2(1), 22-41.

Arifianto, Y. A., \& Purnama, F. (2020). Misiologi dalam Kisah Para Rasul 13 : 47 Sebagai Motivasi Penginjilan Masa Kini. KHARISMA: Jurnal Ilmiah Teologi, 1(2), 117-134.

Arifianto, Y. A., Saptorini, S., \& Stevanus, K. (2020). Pentingnya Peran Media Sosial dalam Pelaksanaan Misi di Masa Pandemi Covid-19. HARVESTER: Jurnal Teologi Dan Kepemimpinan Kristen, 5(2), 86-104. https:// doi.org/10.52104/harvester.v5i2.39

Bibleworks. (n.d.).

Darmawan, I. P. A. (2019). Jadikanlah Murid: Tugas Pemuridan Gereja Menurut Matius 28:18-20. Evangelikal: Jurnal Teologi Injili Dan Pembinaan Warga Jemaat, 3(2), 144-153. Retrieved from https://journal.sttsimpson.ac.id/index.php/EJTI/article/view/138

Denney, A. S., \& Tewksbury, R. (2013). How to Write a Literature Review. Journal 
of Criminal Justice Education, 24(2), 218-234.

https:// doi.org/10.1080/10511253.2012.730617

Dwiraharjo, S. (2019). Kajian Eksegetikal Amanat Agung menurut Matius 28 : 18-

20. Jurnal Teologi Gracia Deo, 1(2), 56-73.

Ermindyawati, L. (2019). Peranan Guru Pendidikan Agama Kristen Terhadap Perilaku Siswa-Siswi Di SD Negeri 01 Ujung Watu Jepara. FIDEI: Jurnal Teologi Sistematika Dan Praktika, 2(1), 40-61. https:// doi.org/10.34081/fidei.v2i1.27

Fitriyana, N., \& Murtiningsih, M. (2019). Matius 28 :19 Analisis Hermeneutik Dalam Tafsiran Alkitab Masa Kini. Jurnal Ilmu Agama: Mengkaji Doktrin, Pemikiran, Dan Fenomena Agama, 20(2). https:/ / doi.org/10.19109/jia.v20i2.5078

Grafura, L., \& Wijayanti, A. (2019). Spirit Pedagogi di Era Disrupsi (Pertama; N. Nihar, Ed.). Yogyakarta: Laksana.

Handoko, Y. T. (2021). Eksposisi Filipi 2:19-24. Surabaya: youtube.com.

Hartono, H. (2018). Mengaktualisasikan Amanat Agung Matius 28:19-20 dalam Konteks Era Digital. KURIOS (Jurnal Teologi Dan Pendidikan Agama Kristen), 4(2), 157-166.

Ina, N. (2018). Peran Guru Pak Dalam Mengatasi Penyembahan Berhala.

Kasali, R. (2017). Strawberry Generation Mengubah Generasi Rapuh menjadi Generasi Tangguh. Jakarta: Penerbit Mizan Anggota IKAPI.

Kasali, R. (2018a). Self Disruption. Jakarta: Mizan Anggota IKAPI.

Kasali, R. (2018b). The Great Shifting. Jakarta: Gramedia Pustaka.

Katarina, K., \& Siswanto, K. (2018). Keteladanan Kepemimpinan Yesus Dan Implikasinya Bagi Kepemimpinan Gereja Pada Masa Kini. Evangelikal: Jurnal Teologi Injili Dan Pembinaan Warga Jemaat, 2(2), 87-98. Retrieved from https://journal.sttsimpson.ac.id/index.php/EJTI/article/view/102

Kia, A. D. (2017). Kajian teologis-pedagogis keteladanan Rasul Paulus dalam penginjilan dan relevansinya bagi pendidik Kristen masa kini. Shanan Jurnal Pendidikan Agama Kristen, 1(2), 74-102.

Lase, D., \& Hulu, E. D. (2020). Dimensi Spritualitas dalam Kompetensi Kepribadian Guru Pendidikan Agama Kristen. SUNDERMANN: Jurnal Ilmiah Teologi, Pendidikan, Sains, Humaniora Dan Kebudayaan, 13(1), 13-25. https:// doi.org/10.36588/sundermann.v13i1.24

Manullang, M. (2019). Peranan Guru Pendidikan Agama Kristen (Pak) Dalam Penginjilan. Jurnal Christian Humaniora, 3(1), 30-26. 
Mary, E., \& Darmawan, I. P. A. (2018). Guru Agama Kristen Yang Profesional. Salatiga: Satya Wacana University Press.

Munthe, E. (2019). Mengoptimalkan Karunia dalam Jemaat untuk Melakukan Misi Amanat Agung di Era 4.0. EPIGRAPHE: Jurnal Teologi Dan Pelayanan Kristiani, 3(2), 133. https:// doi.org/10.33991/epigraphe.v3i2.127

MySabda Team. (2021). MySabda Study Bible.

Ngalimun. (2020). Strategi Pendidikan Akhlak bagi Generasi Muda di Era Disrupsi. TA'LIM : Jurnal Studi Pendidikan Islam, 3(2), 2.

Ngau, D. (2019). Analisis Peranan Guru Pendidikan Agama Kristen Terhadap Pertumbuhan Iman Siswa Kelas V SDN Gugus II Malinau Utara (Sekolah Tinggi Theologia Jaffray). Sekolah Tinggi Theologia Jaffray. https:// doi.org/10.31219/osf.io/m3kjh

Onglo, R. L. (2020). Implementasi Pemuridan Kontekstual Peran Guru Pak Sebagai Konselor Terhadap Perilaku Remaja ( Siswa).

Oni, O. (2020). Prinsip Perintah Yesus untuk Menjadikan Murid Berdasarkan Matius 28:16-20. HUPERETES: Jurnal Teologi Dan Pendidikan Kristen, 1(2), 140-149. https:// doi.org/10.46817/huperetes.v1i2.24

Pawson, D. (2015). Unlocking the New Testament Part 2 - Matthew 2. David Pawsonofficial.

Pawson, D. (2017). Unlocking The Bible. www.davidpawson.org.

Pratiwi, R. S. (2020). Stres Belajar Online Picu Remaja Bunuh Diri, Apa Komentar Psikolog?

Prijanto, J. H. (2017). Panggilan Sebagai Guru Kristen Wujud Amanat Agung Yesus Kristus Dalam Penanaman Nilai Alkitabiah Pada Era Digital. Polyglot: Jurnal Ilmiah, 13(2), 99-107. https:/ / doi.org/10.19166/pji.v13i2.325

Purba, A. (2014). Pemuridan sebagai tugas dosen pendidikan agama kristen di perguruan tinggi. Jurnal TEDC, 8(1), 68-73.

Purnomo, A., \& Sanjaya, Y. (2020). Tantangan dan Strategi Gereja Menjalankan Misi Allah dalam Menghadapi Penerapan Industri 4.0 di Indonesia. DIEGESIS: Jurnal Teologi Kharismatika, 3(2), 91-106.

Putra, A. (2018). Memahami Bangsa-bangsa Lain dalam Injil Matius. BIA': Jurnal Teologi Dan Pendidikan Kristen Kontekstual. https:/ / doi.org/10.34307/b.v1i2.59

Rampa, P. (2020). Pentingnya Pemuridan Kontekstual Bagi Jurusan Pak Agar Menjadi Lulusan Yang Berkualitas Di Masyarakat. In Jurnal IAKN Toraja. https:// doi.org/10.31219/osf.io/aedcu 
Silaban, D. R. (2018). Peran Guru Pendidikan Agama Kristen Sebagai Konselor Bagi Perubahan Perilaku. Jurnal Pendidikan Agama Kristen Regula Fidei, 3(1), 459-481.

Situmorang, S. (2017). Motivasi Panggilan Guru PAK. Kerusso: Jurnal Teologi Dan Pendidikan Agama Kristen, 1(1), 1-14.

Stevanus, K. (2020). Karya Kristus Sebagai Dasar Penginjilan di Dunia NonKristen. Fidei: Jurnal Teologi Sistematika Dan Praktika, 3(1), 1-19. https:// doi.org/10.34081/fidei.v3i1.119

Subekti, T., \& Pujiwati. (2019). Pemuridan Misioner dalam Menyiapkan Perluasan Gereja Lokal. EPIGRAPHE: Jurnal Teologi Dan Pelayanan Kristiani, 3(2), 157. https://doi.org/10.33991/epigraphe.v3i2.126

Suwardana, H. (2018). Revolusi Industri 4. 0 Berbasis Revolusi Mental. JATI UNIK: Jurnal Ilmiah Teknik Dan Manajemen Industri, 1(1), 102. https:// doi.org/10.30737/jatiunik.v1i2.117

Tanduklangi, R. (2020). Analisis Tentang Tujuan Pendidikan Agama Kristen (PAK) Dalam Matius 28:19-20. PEADA' : Jurnal Pendidikan Kristen, 1(1), 4758. https://doi.org/10.34307/ peada.v1i1.14

Telaumbanua, A. (2018). Peranan Guru Pendidikan Agama Kristen Dalam Membentuk Karakter Siswa. FIDEI: Jurnal Teologi Sistematika Dan Praktika, 1(2), 219-231. https://doi.org/10.34081/ fidei.v1i2.9

Tenibemas, P. (2019). Andil Kita Dalam Misi Masa Kini. Pengarah: Jurnal Teologi Kristen, 1(1), 23-36. https:// doi.org/10.36270/pengarah.v1i1.4

Umrati, \& Wijaya, H. (2020). Analisis Data Kualitatif Teori Konsep dalam Penelitian Pendidikan. Sulawesi Selatan: Sekolah Tinggi Theologia Jaffray.

Widjaja, F. I., Ginting, D., \& Hutagalung, S. M. (2019). Teologi Misi sebagai Teologi Amanat Agung. Thronos, 1(1), 17-24.

Yanti, R. (2020). Misi Guru Pak Dalam Lingkup Anak Sekolah Minggu Di Jemaat Gkiige'Tengan. https://doi.org/10.31219/osf.io/yazwe

Yen, E. G. (2019). Tinjauan Ulang Penginjilan Pribadi Dalam Kerangka Amanat Agung Tuhan Yesus Melalui Eksposisi Matius 28:19-20. Jurnal Mahasiswa Teologi Iman, 5(1), 31-48. 